\title{
СТРУКТУРА ТА ЗМІСТ ПРОГРАМИ ФОРМУВАННЯ ВЗАЕМОВІДНОСИН СТАРШИХ ДОШКІЛЬНИКІВ ІЗ СИНДРОМОМ ДАУНА
}

Ірина Михновецька, Інституту спеціальної педагогіки і психології НАПН України імені Миколи Ярмаченка Київ, Україна irina.23061990@gmail.com

Детально описано та обґрунтовано сутність програми формування взаємовідносин старших дошкільників із синдромом Дауна. Зазначено мету, завдання та структурні елементи програми. Детально проаналізовано прийоми роботи та теми занять. Програма подана у таблиці для кращого усвідомлення всіх структурних компонентів та кращого розуміння сутності реалізації в процесі навчально-виховної роботи. Програма побудована 3 опорою на компоненти взаємовідносин, а саме: інтрасуб'єктний та інтерсуб'єктний. Кожне заняття поділене на вступну, основну та завершальнучастини для кращого розуміння і реалізації завдань педагогом під час діяльності. Також визначено етапи роботи (підготовчий, корекційно-розвивальний та завершальний) із зазначенням кількості занять, відповідно до кожного з них.

Ключові слова: програма формування взаємовідносин, діти з синдромом Дауна, компоненти та критерії взаємовідносин.

Ирина Михновецкая, Институт специальной педагогики и психологии имени Николая Ярмаченко НАПН Украины, г. Киев, Украина

Структура и содержание программы формирования взаимоотношений старших дошкольников с синдромом Дауна

Подробно описано и обосновано сущность программы формирования взаимоотношений старших дошкольников с синдромом Дауна. Указано цели, задачи и структурные элементы программы. Детально проанализированы приемы работы и темы занятий. Программа представлена в таблице для лучшего осознания всех структурных компонентов и лучшего понимания сущности реализации в процессе учебно-воспитательной работы. Программа построена с опорой на компоненты взаимоотношений, а именно: интрасубъектный и интерсубъектный. Каждое занятие разделено на вводную, основную и заключительную части для лучшего понимания и реализации задач педагогом во время деятельности. Также определены этапы работы (подготовительный, коррекционно-развивающий и заключительный) с указанием количества занятий, соответствующий каждому из них.

Ключевые слова: программа формирования взаимоотношений, дети с синдромом Дауна, компоненты и критерии взаимоотношений

(c) Михновецька І., 2019 
Iryna Mykhnovetska, Mykola Yarmachenko Institute of Special Education and Psychology of the NAES of Ukraine (Ukraine), Kyiv, Ukraine

Structure and content of the program for formation of relationships of older preschoolers with Down syndrome

The article describes and substantiates the essence of the program of forming relationships between senior preschool children with Down syndrome. The purpose, tasks and structural elements of the program are indicated. The methods of work and the topics of the lessons are analyzed in detail. The program for forming relationships between senior preschool children with Down syndrome is presented in the table for better understanding of all structural components and a better understanding of the essence of implementation in the process of educational work. The program is based on the components of the relationship, namely, intrasubjective and intersubjective. Each lesson is divided into the introductory, main and final parts for better understanding and realization of tasks by the teacher during the activity. Also, the stages of work (preparatory, corrective-developing and final) are indicated, indicating the number of occupations corresponding to each of them.

Keywords: program for the formation of relationships, children with Down syndrome, components and criteria for relationships

Актуальність проблеми. Для вирішення нагальних питань та задоволення власних потреб дошкільник має вміти звертатися за допомогою та висловлювати власні прагнення та побажання оточуючим. Тому, формування взаємовідносин є одним з багатьох необхідних процесів для позитивної адаптації у соціумі.

Діти з синдромом Дауна мають труднощі формування взаємовідносин. Вони не можуть самостійно співпрацювати та організовувати свою діяльність. Не розуміють елементарних правил гри та потребують додаткових пояснень та стимуляції. У дітей з синдромом Дауна порушена пізнавальна активність, вищі психічні функції та здатність усвідомлювати себе повноцінним членом діяльності. Саме тому нами була створена програма формування взаємовідносин у старших дошкільників із синдромом Дауна, ї̈ зміст представлено нижче.

Корекційно-розвивальна програма базувалась на моделях та алгоритмах формування взаємовідносин з урахуванням системного, особистісного, діяльнісного, полісуб'єктного методологічних підходів та педагогічних принципів цілісності, структурності, взаємозалежності зовнішніх та внутрішніх чинників взаємовідносин, ієрархічності та множинності уявлення системи взаємовідносин. Під час організації корекційно-розвивальної роботи ми враховували такі важливі аспекти як форма проведення, час та систематичність здійснення педагогічного впливу і залучення додаткових інструментів.

«ОСОБЛИВА ДИТИНА: навчання і виховання», № 3, 2019 
Аналізнаукових джерел. У процесі роботи над програмою формування взаємовідносин старших дошкільників із синдромом Дауна нами було проаналізовано матеріали з дошкільної та спеціальної психології та педагогіки, вікові й психологічні особливості розвитку дошкільників та розвиток взаємовідносин у дітей $з$ психофізичними порушеннями. Було враховано основний вид діяльності дошкільників та проаналізовано роботи з ігрової діяльності О. Запорожця, Е. Ельконіна. А. Тюкова, С. Неверковіч, В. Лазарева, О. Анісімова, Г. Щедровицького та ін. [1; 2].

Були проаналізовані положення Л. Виготського про зону актуального та найближчого розвитку, що допомогли правильно спроектувати етапи реалізації програми та їі основний зміст. Розглядалися питання реалізації навчально-виховного процесу в закладах дошкільної освіти, аналізувалася медична література щодо особливостей розвитку дітей із синдромом Дауна, зверталась увага на їх інтелектуальний розвиток, фізичні можливості, рухові навички, поведінку та емоції. Під час взаємодії з дітьми з синдромом Дауна застосовували докладне пояснення та чітку інструкцію. Додатково була проаналізована література щодопорушення психофізичного розвитку у дітей із синдромом Дауна зарубіжних учених (J. Baker, W. Brown, M. Guralnick, R. Fenning, R. McConnell) [3;4]. У результаті, нами було враховано вікові та індивідуальні можливості, а також особливості компенсаторних механізмів та здатність до наслідування таких дітей.

Виклад основного матеріалу. Мета програми полягала у формуванні позитивних взаємовідносин у старших дошкільників із синдромом Дауна.

Відповідно до мети було розроблено такі завдання програми:

- реалізація педагогічних, психологічний та організаційних умов формування взаємовідносин як передумова позитивного впровадження програми;

- формування інтрасуб'єктного компоненту взаємовідносин;

- формування інтерсуб'єктного компоненту взаємовідносин.

Структура кожного заняття охоплювала вступ, основну та завершальну частини. Вступ передбачав привітання та організаційний момент. Привітання здійснювалось для того, щоб стимулювати дітей до початку активності, концентрувати їх увагу та налаштувати на подальшу діяльність. Організаційний момент мав на меті правильно організувати дітей до діяльності: на основі легких вправ підвести до виконання більш складних завдань. Привітання та організаційний момент є невід’ємною складовою будь-якого заняття, ці елементи після кількаразового застосування стимулюють дитину до усвідомлення того, що заняття почалось і буде виконуватись нова цікава діяльність.

В основній частині представлено вправи для реалізації конкретної мети, що заохочує формування взаємовідносин у дітей з синдромом Дауна. Під час 


\section{BEKSOP TPAHROCOPMANUIII}

виконання завдань увага приділяється стимулюванню та мотивуванню дошкільників та реалізовується за допомогою спеціально організованої роботи педагога та залучення відповідного інструментарію. Також було використано різноманітні методи, прийоми та засоби педагогічного впливу для кращої реалізації мети. Завдання, що пропонувались дітям були спрямовані на розвиток не тільки розумової діяльності, а також рухової, емоційно-вольової та поведінкової сфер. Кількість завдань на занятті варіювалась від 4 до 6 залежно від тривалості вправ і розумових та фізичних затрат на правильне їх виконання.

Завершальна частина передбачала релаксацію та прощання. Релаксація застосовувалась для розслаблення м'язів дитини після фізичної активності, налаштування на кінець заняття. Прощання допомагає дітям із синдромом Дауна зрозуміти, що мету заняття було реалізовано.

У процесі реалізації програми формування взаємовідносин зверталася увага на швидкість виконання завдань, якість іх здійснення, швидкість втомлюваності дитини та на те, які емоції виникали: позитивні чи негативні. Якщо дитина самостійно не могла відразу виконати запропоноване завдання, то педагог-помічник допомагав їй, підтримував, вказував куди необхідно піти і що взяти, допомагав утримувати необхідний предмет, підтримував руки дитини під час виконання ними рухів. Відмічали не тільки повністю виконане завдання дітьми, а й ті малі позитивні зміни, що спостерігались у порівняні з минулим.

Програма передбачала 2 блоки, відповідно до компонентів взаємовідносин і характеризуються такими критеріями як: установочно-мотиваційний, когнітивно-афективний, конативний та диспозиційний. У кожному блоці було виділено завдання, що відповідали підготовчому, корекційно-розвивальному та завершальному етапам.

За допомогою поділу програми на блоки ми змогли компактно та мобільно представити основні їі структурні елементи та прийоми роботи (таблиия).

Перший блок - формування інтрасуб'єктного компоненту здійснювався у рамках роботи над установочно-мотиваційним та когнітивно-афективним критеріями.

Реалізація роботи над кожним критерієм мала свою мету, завдання, прийоми роботи та передбачала засвоювання вище зазначеного у відповідних темах занять. Крім того заняття було дібрано відповідно до етапів, що ми запропонували вище: підготовчий - для налаштування дитини до діяльності й кращої роботи над відповідним компонентом, корекційно-розвивальний, у якому проводилась основна робота з формування компоненту взаємовідносин з опорою на окремий критерій та завершальний - для узагальнення отриманої інформації та іï закріплення.

«ОСОБЛИВА ДИТИНА: навчання і виховання», № 3, 2019 
Структура та зміст програми формування взаємовідносин у старших дошкільників із синдромом Дауна

\begin{tabular}{|c|c|c|c|c|c|}
\hline \multirow{3}{*}{ 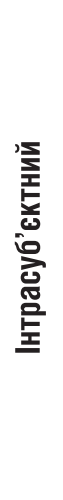 } & \multirow{3}{*}{ 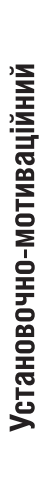 } & Етапи & Підготовчий & Корекційно-розвивальний & Завершальний \\
\hline & & Мета & \multicolumn{3}{|c|}{$\begin{array}{l}\text { Стимулювати до формування позитивних соціальних установок, вчити } \\
\text { правильно орієнтуватися у ситуації навколишньої дійсності та приймати } \\
\text { самостійні рішення відповідно до ситуацій }\end{array}$} \\
\hline & & Завдання & $\begin{array}{l}\text { Підготувати } \\
\text { дошкільників до } \\
\text { діяльності у малій } \\
\text { групі та парах, } \\
\text { допомогти зрозуміти } \\
\text { як правильно } \\
\text { взаємодіяти } 3 \\
\text { іншими }\end{array}$ & $\begin{array}{l}\text { Стимулювати до спільної } \\
\text { діяльності, вчити } \\
\text { приймати допомогу інших } \\
\text { під час діяльності }\end{array}$ & $\begin{array}{l}\text { Активізувати прагнення } \\
\text { працювати у команді } \\
\text { та парах, допомагати } \\
\text { іншим без допомоги } \\
\text { дорослого, закріпити } \\
\text { раніше запропонований } \\
\text { матеріал }\end{array}$ \\
\hline & & Прийоми & \multicolumn{3}{|c|}{$\begin{array}{l}\text { Пояснення. } \\
\text { Власний приклад виконання дій. } \\
\text { Робота } 3 \text { реальними предметами. } \\
\text { Активні рухові вправи. } \\
\text { Релаксація }\end{array}$} \\
\hline & & Теми & № 1. Я не один & $\begin{array}{l}\text { № 2. Допомагати - це } \\
\text { добре. № 12. Якщо } \\
\text { я впаду, то піднятись } \\
\text { зможу сам }\end{array}$ & $\begin{array}{l}\text { № } 6 \text { я не лінуюся. № } \\
\text { 15. У нас все завжди } \\
\text { виходить вдало }\end{array}$ \\
\hline & \multirow{4}{*}{ 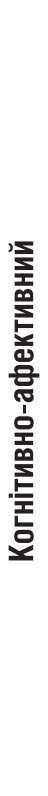 } & Мета & \multicolumn{3}{|c|}{$\begin{array}{l}\text { Стимулювати розвиток вищих психічних функцій: пам'ять, мислення, } \\
\text { мовлення; вчити концентруватита переключати увагу, збагачувати емоційні } \\
\text { реакції, коригувати поведінкову сферузалежно від ситуації }\end{array}$} \\
\hline & & Завдання & $\begin{array}{l}\text { Налаштувати } \\
\text { дошкільників на } \\
\text { тривалу взаємодію } \\
3 \text { залученням } \\
\text { розумової активності }\end{array}$ & $\begin{array}{l}\text { Учити концентруватись } \\
\text { на окремих предметах } \\
\text { та здійснювати з ними } \\
\text { дії, словесно відповідати } \\
\text { на прохання дорослого, } \\
\text { проявляти бажання до } \\
\text { позитивного завершення } \\
\text { завдання }\end{array}$ & $\begin{array}{l}\text { Правильно взаємодіяти } \\
\text { з іншими під час } \\
\text { виконань складних } \\
\text { інтелектуальних } \\
\text { завдань, допомагати } \\
\text { іншим за необхідності, } \\
\text { проявляти адекватні } \\
\text { емоції відповідно до } \\
\text { ситуації }\end{array}$ \\
\hline & & Прийоми & \multicolumn{3}{|c|}{$\begin{array}{l}\text { Усвідомлення власної значущості за допомогою словесних заохочень } \\
\text { педагога. } \\
\text { Активізація прагнень до самовираження. } \\
\text { Акцентуація на правильно виконаних завданнях }\end{array}$} \\
\hline & & Теми & № 7. Обійми друга & $\begin{array}{l}\text { № 4. Граємось разом. № } \\
\text { 11. Музичний оркестр }\end{array}$ & $\begin{array}{l}\text { № 13. Усміхнись і } \\
\text { потрудись. № } 14 \text {. } \\
\text { Любим разом ми } \\
\text { співати (навчатись) }\end{array}$ \\
\hline
\end{tabular}




\begin{tabular}{|c|c|c|c|c|c|}
\hline \multirow{4}{*}{ 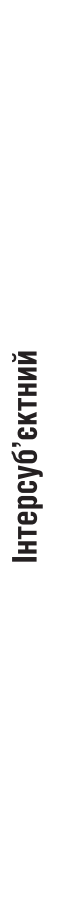 } & \multirow{4}{*}{$\begin{array}{l}\text { 空 } \\
\text { 产 } \\
\text { 产 } \\
\text { 产 }\end{array}$} & Мета & \multicolumn{3}{|c|}{$\begin{array}{l}\text { Учити правильно взаємодіяти з іншими та корегувати свою поведінку } \\
\text { в залежності від ситуацій навколишньої дійсності, вчасно проявляти } \\
\text { задоволення, незадоволення, підлягати під загальноприйняті правила } \\
\text { поведінки серед оточуючих }\end{array}$} \\
\hline & & Завдання & $\begin{array}{l}\text { Допомагати } \\
\text { сприйняти правила } \\
\text { поводження } \\
\text { у колективі } \\
\text { однолітків, сприяти } \\
\text { налагодженню } \\
\text { контактів } 3 \\
\text { оточуючими, } \\
\text { стимулювати } \\
\text { прагнення до } \\
\text { адекватної взаємодії } \\
3 \text { іншими }\end{array}$ & $\begin{array}{l}\text { Стимулювати до } \\
\text { корегування поведінки } \\
\text { інших, самостійно } \\
\text { усвідомити ситуації } \\
\text { пасивної поведінки інших, } \\
\text { емоційно показувати } \\
\text { результати задоволення } \\
\text { своєю діяльністю }\end{array}$ & $\begin{array}{l}\text { Допомагати іншим } \\
\text { усвідомити помилки } \\
\text { виконуваної діяльності, } \\
\text { налаштовувати } \\
\text { на максимальну } \\
\text { позитивну взаємодію } 3 \\
\text { однолітками, проявляти } \\
\text { почуття незадоволення } \\
\text { під час неправильно } \\
\text { виконаній діяльності }\end{array}$ \\
\hline & & Прийоми & \multicolumn{3}{|c|}{$\begin{array}{l}\text { Усвідомлення загальноприйнятим правилам поведінки. } \\
\text { Усвідомлення відхилень у поведінки інших дошкільників. } \\
\text { Корекція негативних поведінкових реакцій інших }\end{array}$} \\
\hline & & Теми & $\begin{array}{l}\text { № 9. Слухаємо } \\
\text { дорослого }\end{array}$ & $\begin{array}{l}\text { № 16. Я поважаю } \\
\text { вихователя. № } 17 \text {. Я } \\
\text { люблю батьків }\end{array}$ & $\begin{array}{l}\text { № 18. Різні ігри } \\
\text { граємо і всього } \\
\text { навчаємось. №20. } \\
\text { Спорт і я дружня сім'я }\end{array}$ \\
\hline & \multirow{4}{*}{ 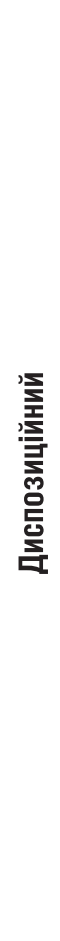 } & Мета & \multicolumn{3}{|c|}{$\begin{array}{l}\text { Учити займати певну позицію під час діяльності орієнтуватись та } \\
\text { прагнення та бажання інших, появляти індивідуальні риси особистості: } \\
\text { активність, згуртованість залучення до спільної діяльності та виконувати } \\
\text { відповідні ролі під час виконання завдань }\end{array}$} \\
\hline & & Завдання & $\begin{array}{l}\text { Учити усвідомлювати } \\
\text { власні роді під } \\
\text { час діяльності, } \\
\text { підлягати під спільні } \\
\text { правила діяльності, } \\
\text { показувати іншим } \\
\text { необхідні дії під } \\
\text { час виникнення } \\
\text { ситуацій нерозуміння } \\
\text { завдання }\end{array}$ & $\begin{array}{l}\text { Коригувати власні } \\
\text { дії відповідно до } \\
\text { можливостей інших, } \\
\text { проявляти бажання } \\
\text { активної допомоги } \\
\text { під часзавдань, } \\
\text { стимулювати інших до } \\
\text { виконання спільних } \\
\text { правил у діяльності для } \\
\text { позитивного правильного } \\
\text { завершення діяльності }\end{array}$ & $\begin{array}{l}\text { Учити правильно } \\
\text { орієнтуватись у } \\
\text { завданні після } \\
\text { безпосереднього його } \\
\text { показу, брати на себе } \\
\text { відповідальність під } \\
\text { час роботи у парах, } \\
\text { проявляти активність, } \\
\text { допомагати найбільш } \\
\text { пасивним одноліткам } \\
\text { коригувати ситуації } \\
\text { неуспіху }\end{array}$ \\
\hline & & Прийоми & \multicolumn{3}{|c|}{$\begin{array}{l}\text { Коригування дій інших. } \\
\text { Самостійне усвідомлення помилок у діяльності. } \\
\text { Прояв лідерських якостей. } \\
\text { Можливість впливу дошкільника на інших без залучення допомоги } \\
\text { дорослого }\end{array}$} \\
\hline & & Теми & $\begin{array}{l}\text { № 5. Одягаємось } \\
\text { разом }\end{array}$ & $\begin{array}{l}\text { № 3. } 1,2,3-\text { рухливу } \\
\text { гру ми почали. № } 10 . \\
\text { Слово і рух - одне ціле }\end{array}$ & $\begin{array}{l}\text { № 8. Танцюємо разом. } \\
\text { № 19. Сюжетно } \\
\text { рольові ігри }\end{array}$ \\
\hline
\end{tabular}


Як зазначалося, перед упровадженням програми нами була проведена попередня робота з педагогами, що співпрацюють із дітьми з синдромом Дауна та батьками дошкільників. Робота мала на меті ознайомити найближче оточення дітей з синдромом Дауна з доцільністю іï провадження та окреслити можливі позитивні результати. Просвітницька робота здійснювалась у вигляді консультацій, бесід та за індивідуальної ініціативи дорослих за потребою.

Формування інтрасуб'єктного компонента здійснювалось за допомогою поетапної роботи над кожним його критерієм. Перший критерій - це установочно-мотиваційний. Метою було стимулювати дітей до формування соціальних установок, вчити правильно орієнтуватись на ситуації навколишньої дійсності та приймати самостійні рішення відповідно до ситуацій. Реалізація мети здійснювалась за допомогою поділу занять відповідно до етапів. Так, підготовчий етап передбачав одне заняття, а корекційно-розвивальний та завершальний по два. На підготовчому етапі заняття тема: «Я не один» стимулювало дошкільників до налаштування до діяльності та прийнятті самостійних рішень. Вони навчались розуміти завдання, які їм пропонували та реагувати відповідно до ситуації. Завданнями заняття на підготовчому етапі було: підготувати дошкільників до діяльності у групах та парах; допомогти зрозуміти як правильно взаємодіяти $з$ іншими.

Отже, спершу необхідно було правильно згуртувати дошкільників та допомогти їм зрозуміти діяльність, що пропонувалась на занятті.

На корекційно-розвивальному етапі було реалізовано два заняття $з$ тем: «Допомагати - це добре», «Якщо я впаду, то піднятись зможу сам». Його завданнями стало: стимулювати до спільної діяльності; вчити приймати допомогу інших під час діяльності.

Тобто, увага зосереджувалась на усвідомленні інших під час діяльності та прагненні допомагати іншим для позитивного вирішення запропонованих завдань.

Завершальний етап також реалізовувався за допомогою двох занять і тем: «Я не лінуюся» та «В нас все завжди виходить вдало». Так як у дітей з синдромом Дауна наявна розумова відсталість, то їм притаманно швидко забувати засвоєне раніше. Тому нами було вирішено закріпленню приділити максимально велику кількість занять.

Завданнями завершального етапу стали: активізувати прагнення дошкільників працювати у команді та парах; допомагати іншим дітям із синдромом Дауна без допомоги дорослого; закріпити раніше запропонований матеріал.

На запропонованих заняттях було залучено компенсаторні механізми дошкільників із синдромом Дауна, а саме здатність до наслідування та емоційна позитивна налаштованість до діяльності. Увага приділялась точним та чітким 


\section{BEKSOP TPAHRGOPMMANUIII}

інструкціям, багаторазовим показам правильного виконання завдання та коригуванням дій дошкільника у разі виникнення помилок.

У процесі роботи були задіяні різноманітні прийоми роботи, а саме: пояснення; власний приклад виконання дій; робота з реальними предметами; активні рухові вправи; релаксація.

Когнітивно-афективний критерій інтрасуб'єктного компонента. Під час роботи була проектована загальна мета роботи за цим критерієм: стимулювати розвиток вищих психічних функцій: пам'ять, мислення, мовлення; учити концентруватита переключати увагу, збагачувати емоційні реакції, коригувати поведінкову сферу залежно від ситуації.

Підготовчий етап реалізувався за допомогою заняття з теми: «Обійми друга». На ньому стимулювалась розумова активність дошкільників та прагнення досягти позитивних результатів, вправи пропонувалися ознайомчого характеру з залученням мінімальної кількості розумових операцій.

Його завданням стало: налаштувати дошкільників на тривалу взаємодію 3 залученням розумової активності.

Розумова активність є найважчою для дітей із синдромом Дауна, їм важко осмислити дії, що вони виконують та зробити висновки щодо вже отриманих результатів, у них порушені причинно-наслідкові зв'язки та наявні труднощі запам'ятовування.

Корекційно-розвивальний етап включав два заняття 3 тем: «Граємось разом», «Музичний оркестр».

Його завданнями стали: вчити концентруватись на окремих предметах; здійснювати необхідні маніпуляції з предметами; словесно відповідати на прохання дорослого; проявляти бажання до позитивного завершення завдання.

Отже, увага приділялась не тільки правильному результату виконання діяльності, а й емоційним реакціям дошкільника в процесі роботи.

Завершальний етап проводився з використанням таких тем занять: «Усміхнись і потрудись», «Любим разом ми навчатись».

Його завданнями були: постійно стимулювати дітей до розумової активності; підтримувати віру у власні сили дошкільників для позитивного завершення завдань; вчити правильно взаємодіяти з іншими під час виконань складних інтелектуальних завдань; допомагати іншим дошкільникам при необхідності; проявляти адекватні емоції відповідно до ситуаціі.

Додатковими прийомами роботи стали:

- усвідомлення власної значущості за допомогою словесних заохочень педагога;

- активізація прагнень до самовираження;

- акцентуація на правильно виконаних завданнях.

«ОСОБЛИВА ДИТИНА: навчання і виховання», № 3, 2019 
Отже, у процесі роботи було впроваджено інтелектуальні завдання - для роботи над психічними функціями, емоційно насиченні завдання - для стимуляції допомагати іншим та дисципліновані завдання - для роботи з корегуванням поведінки у разі необхідності.

Формування інтерсуб'єктного компонента передбачала роботу з конативним та диспозиційним критеріями. Мета роботи над конативним критерієм полягала у навчанні дошкільників правильно взаємодіяти з іншими та корегувати власну поведінку залежно від ситуацій навколишньої дійсності, вчасно проявляти задоволення, незадоволення, підлягати під загальноприйняті правила поведінки серед оточуючих.

На підготовчому етапі відповідно до неї були реалізовані наступні завдання 3 теми «Слухаємо дорослого»: допомагати сприйняти правила поводження у колективі однолітків; сприяти налагодженню контактів з оточуючими; стимулювати прагнення до адекватної взаємодії з іншими.

Тобто увага приділялась правильній поведінці на занятті та емоційним та руховим реакціям дошкільника під час діяльності.

Корекційно-розвивальний етап реалізовувався з таких тем занять: «Я поважаю вихователя», «Я люблю батьків».

Його завданнями стали: стимулювати до корегування поведінки інших дошкільником з синдромом Дауна; самостійно усвідомити ситуації пасивної поведінки інших; емоційно показувати результати задоволення своєю діяльністю.

Під час роботі простежувались позитивні зміни поведінки дітей при виконанні запропонованих завдань та можливості коригування іiі у діяльності.

Завершальний етап проводився на заняттях 3 тем: «Різні ігри граємо і всього навчаємось», «Спорт і я дружня сім'я».

Його завданнями стали: допомагати іншим усвідомити помилки виконуваної діяльності;налаштовувати на максимальну позитивну взаємодію з однолітками; проявляти почуття незадоволення власним результатом якщо неправильно виконане завдання.

Додатковими прийомами роботи виступили:

- підпорядковування загальноприйнятим правилам поведінки;

- усвідомлення відхилень у поведінки інших дошкільників;

- корекція негативних поведінкових реакцій інших.

Диспозиційний критерій мав на меті навчити займати певну позицію під час діяльності, орієнтуватись на прагнення та бажання інших, проявляти індивідуальні риси особистості: активність, згуртованість, залучення до спільної діяльності та виконання відповідних ролей під час реалізації запропонованих завдань. 


\section{BEKSOP TPAHROCOPMANUIII}

На підготовчому етапі реалізовувались такі завдання як: учити усвідомлювати власні ролі під час діяльності: виконувати спільні правила діяльності; показувати іншим правильні дії під час виникнення ситуацій нерозуміння завдання.

Тобто, акцентування відбувалося на ролі дитини під час діяльності, яку вона позицію займає і як ії вибір упливає на єдиний спільний результат. Тема: «Одягаємось разом».

Корекційно-розвивальний етап реалізовувався на заняттях з тем: «1, 2, 3 рухливу гру ми почали», «Слово і рух - одне ціле».

Його завданнями стали: коригувати власні дії відповідно до можливостей інших; проявляти бажання активної допомоги під час реалізації завдань; стимулювати інших до виконання спільних правил діяльності для позитивного правильного завершення завдань.

Найбільша увага приділялась не тільки власним бажанням, прагненням та поведінці дитини, а й тому, наскільки дитина з синдромом Дауна може оцінити дії інших й чи може впливати на їню поведінку якщо є необхідність.

Завершальний етап охоплював два заняття з тем: «Танцюємо разом», «Сюжетно-рольові ігри».

Його завданнями були: вчити правильно орієнтуватись у завданні після безпосереднього його показу; брати на себе відповідальність під час роботи у парах; проявляти активність у діяльності; допомагати найбільш пасивним одноліткам згладжувати ситуації неуспіху.

Додатковими приймами роботи стали:

- коригування дій інших;

- самостійне усвідомлення помилок у діяльності;

- прояв лідерських якостей;

- можливість позитивного впливу дошкільника на інших без залучення дорослого.

Висновки. Формування інтерсуб'єктного компонента взаємовідносин реалізовував прагнення дошкільника займати провідні соціальні ролі, проявляти адекватну поведінку серед однолітків, контролювати спільну діяльність, робити самостійні умови щодо власних помилок та помилок інших.

Тобто в процесі реалізації програми робота проводилась над тим, щоб кожен дошкільник з синдромом Дауна усвідомив значущість своїх дій та дій оточуючих для плідної співпраці як на занятті, так і в майбутній виконуваній діяльності.

Отже, формування взаємовідносин - це складний процес, під час якого залучаються усі психічні функції, формується самоусвідомлення дитини, реалізуються прагнення дошкільника та спостерігається тенденція до позитивної соціалізації у суспільстві.

«ОСОБЛИВА ДИТИНА: навчання і виховання», № 3, 2019 
У результаті, можна стверджувати про необхідність корекційного впливу на дошкільників із синдромом Дауна у формуванні взаємовідносин.

Програма формування взаємовідносин забезпечує налагодження позитивної взаємодії дошкільників з синдромом Дауна 3 іншими, стимулює інтерес до діяльності однолітків, навчає взаємодіяти та бути повноцінним учасником діяльності.

\section{ЛITEPATУPA}

1. Тюков А. А. Психология образования: учеб. пособие для бакалавриата и магистратуры / А. А. Тюков. - М. : Издательство Юрайт, 2019. - 177 с. (2-е изд., перераб. и доп.).

2. ЩедровищькийГ. Схеми миследіяльності - системно-структурна будова, значення і зміст / Георгій Щедровицький// Психологія і суспільство. - 2005. - № 4. - С. 29-39.

3. Baker JK, Fenning RM, Crnic KA, Baker BL, BlacherJ. Prediction of social skills in 6-year-old children with and without developmental delays: Contributions of early regulation and maternal scaffolding. American Journal on Mental Retardation. 2007;112:375-391.

4. Michael J. Guralnick, PhD. Early Intervention Approaches to Enhance the Peer-Related Social Competence of Young Children With Developmental Delays A Historical Perspective. Infants Young Child. 2010 Apr; 23(2): 73-83.doi: 10.1097/IYC.0b013e3181d22e14

\section{REFERENCES (TRANSLATED AND TRANSLITERATED)}

1. Tjukov A. A. Psihologija obrazovanija: ucheb. posobie dlja bakalavriata i magistratury / Anatolij Aleksandrovich Tjukov. - M. : Izdatel'stvo Jurajt, 2019. - 177 s. (2-e izd., pererab. i dop.).

2. Shchedrovytskyi H. Skhemy myslediialnosti - systemno-strukturna budova, znachennia i zmist /H.Shchedrovytskyi// Psykholohiia i suspilstvo. - 2005. - № 4. - S. 29-39. 